\title{
Tariffavtaler, rettsutvikling - og organisasjonsfrihet
}

Av postdoktor ph.d. Marianne Jenum Hotvedt

\section{Introduksjon}

Temaet for denne artikkelen er rettsutviklingens betydning for tariffavtaler og tariffpartenes ansvar. ${ }^{1}$ Temaet er praktisk viktig. Tariffavtaledekningen i Norge er relativt høy, den er praktisk talt 100 prosent i offentlig sektor og nær 60 prosent i privat sektor. ${ }^{2}$ Samspillet mellom tariffavtale og lov er derfor helt vesentlig for å forstå reguleringen av arbeidslivet. Temaet er også prinsipielt viktig. Forholdet mellom lov og tariffavtale reiser spørsmål om hvorvidt organisasjonsfrihet og prinsipper om kollektiv autonomi setter skranker for lovgiver. Rettsutviklingen har dessuten styrket organisasjonsfrihetens stilling i norsk rett.

Innledningsvis presenterer jeg tariffavtalen som reguleringsinstrument (punkt 2) og utgangspunktet om organisasjonsfrihet og kollektiv autonomi (punkt 3). Jeg drøfter den rettsutviklingen som skjer gjennom tariffavtalene selv (punkt 4), og hvordan rettsutvikling ved endringer i lovregler påvirker tariffavtalen (punkt 5). Underveis skisserer jeg hvordan tariffpartene kan stilles til ansvar for de ulike formene for rettsutvikling. Avslutningsvis reises spørsmålet om tariffpartene har et ansvar for å bidra til en bestemt rettsutvikling (punkt 6).

\section{Tariffavtalen som reguleringsinstrument}

Regulering av arbeid bygger på en grunnleggende erkjennelse om at individuell avtalefrihet må begrenses av hensyn til vern av individet. ${ }^{3}$ Avtalefrihet for partene i en arbeidsavtale maksimerte ikke nytte til partenes felles beste, men ga grobunn for utnyttelse og sosiale problemer. Det utløste statlig intervensjon i form av vernelovgivning. Det ga også støtet til kollektiv opptreden og inngåelse av kollektive avtaler. Lovgiver så det etter hvert som sin oppgave å legge til rette for slike avtaler, og ved arbeidstvistlovgivningen ble tariffavtalen uttrykkelig anerkjent som en særegen avtaletype. I dag er tariffavtalen definert i arbeidstvistloven (arbtvl.) $§ 1$ bokstav e: ${ }^{4}$

«en avtale mellom en fagforening og en arbeidsgiver eller arbeidsgiverforening om arbeids- og lønnsvilkår eller andre arbeidsforhold».

\footnotetext{
${ }^{1}$ Artikkelen er basert på min prøveforelesning for graden ph.d., holdt 9. juni 2015. Oppgitt emne var «Betydning av rettsutvikling for eksisterende tariffavtaler og partenes ansvar i den forbindelse». En stor takk til

Arbeidsrettsgruppen ved Institutt for privatrett for innspill under arbeidet med forelesningen, og til Stein Evju for nyttige kommentarer til artikkelen.

${ }^{2}$ Kristine Neergård, Organisasjonsgrader, tariffavtaledekning og arbeidskonflikter 2013, Fafo-notat 2014:14

s. 21.

${ }^{3}$ Arbeiderkommissionens Indstilling I (1888) s. 9-10. Nærmere om verdigrunnlaget, se Marianne Jenum Hotvedt, Arbeidsgiverbegrepet, Oslo 2016 s. 57 flg.

${ }^{4}$ Lov 27. januar 2012 om arbeidstvister.
} 
Avtalen må altså være inngått av en fagforening og en arbeidsgiverforening, eventuelt en enkeltarbeidsgiver. Mange av organisasjonene i arbeidslivet er hierarkisk bygget opp. Når organisasjoner eller bedrifter nedover i hierarkiet inngår avtaler, er det som alminnelig regel den overordnede organisasjonen som er tariffpart. ${ }^{5}$ Den underordnede organisasjonen kan anses som en operativ tariffpart, men er rettslig sett forpliktet av tariffavtalen i kraft av å være medlem i hovedorganisasjonen.

Tariffavtalen har flere lovlignende trekk. Den inneholder bestemmelser om lønns- og arbeidsvilkår for en ubestemt krets av arbeidstakere. ${ }^{6}$ Slike bestemmelser binder flere enn partene, de binder også de medlemmene som omfattes av avtalen, både underorganisasjoner og enkeltmedlemmer. For de medlemsbundne er tariffavtalens regler om lønns- og arbeidsvilkår ufravikelige. Arbtvl. § 6 gir et uttrykk for det: «Bestemmelse i arbeidsavtale som strider mot en tariffavtale som begge parter er bundet av, er ugyldig.»

Tariffavtaler setter altså grenser for avtalefriheten i individuelle arbeidsforhold på lignende måte som lov. De har også betydning for andre arbeidsforhold gjennom ulovfestede prinsipper om ufravikelighet og som deklaratorisk rett. ${ }^{7}$

Hva som «strider mot» tariffavtalen, beror på en tolkning av avtalen. Både fravik til gunst og til skade for arbeidstaker kan stride mot avtalen. Ufravikeligheten skiller seg dermed grunnleggende fra lovfastsatte verneregler, som setter et ufravikelig minimumsnivå for vernet av arbeidstaker.

Tariffavtaler er videre underlagt formkrav. Avtalen skal være skriftlig, og det bør fastsette ikrafttredelsestidspunkt, varighet og oppsigelsesfrist, jf. arbtvl.§ 4. Skriftlighetskravet er en betingelse for at avtalen skal utløse tariffavtalens særlige rettsvirkninger. Det er begrunnet $\mathrm{i}$ behovet for å sikre bevis for at en tariffavtale er inngått og hva den går ut på, noe som kan ses i sammenheng med avtalens tredjemannsvirkninger. ${ }^{8}$

Formelt er tariffavtalen tidsbegrenset og oppsigelig. Arbeidstvistlovens fravikelige regel er tre års varighet, jf. $\S 5$ første ledd. Normalt avtales en varighet på to år. Men i realiteten er tariffavtalen langvarig. Tariffavtalen er treffende betegnet som et bundet partsforhold. ${ }^{9}$ Tariffpartene har ikke noen reell mulighet til å gå ut av avtaleforholdet eller velge seg en annen medkontrahent. Tidsbegrensningen og oppsigelsesadgangen åpner i realiteten ikke for

\footnotetext{
${ }^{5}$ Se for eksempel ARD 1987 s. 111, særlig s. 116-117.

${ }^{6}$ Avtaler som kun regulerer forholdet mellom organisasjonene kan imidlertid også være en tariffavtale, jf. «eller andre arbeidsforhold».

${ }^{7}$ Tariffavtalen forstås i utgangspunktet slik at den forplikter arbeidsgiver til å gi samme vilkår til arbeidstakere som ikke er tariffbundne («utenforstående»), se for eksempel ARD 1922 s. 50. Nærmere om tariffavtalens betydning som deklaratorisk rett, se Aleksander Næss Skjønberg, «Tariffavtalers virkning for utenforstående arbeidstakere», Arbeidsrett, 2011 s. 1-80, særlig på s. 49-56.

${ }^{8}$ ARD 1918-19 s. 79, se også Torgeir Aarvaag Stokke, Kristine Neergard og Stein Evju, Det kollektive arbeidslivet, 2. utgave, Oslo 2013 s. 131.

${ }^{9}$ Terese Smith Ulseth, «Hva er så spesielt med tariffavtaler», Arbeidsrett og arbeidsliv, Bind 6 s. 325-340

(2012), på s. 334.
} 
at avtalen faller bort, men sikrer jevnlig revidering. ${ }^{10}$ Tariffavtalen legger dermed i praksis varige begrensninger for individuell avtalefrihet.

\section{Organisasjonsfriheten og kollektiv autonomi}

Organisasjonsfrihet er en grunnleggende rettighet med forankring i Grunnloven $\S 101$ og en rekke internasjonale konvensjoner, blant andre Den europeiske menneskerettskonvensjon (EMK) art. 11, FN-konvensjonen om sivile og politiske rettigheter (SP) art. 22 og FNkonvensjonen om $\varnothing$ konomiske, sosiale og kulturelle rettigheter (ØSK) art. 8. ${ }^{11}$ Disse bestemmelsene gjelder som norsk rett med forrang ved motstrid med annen norsk rett, jf. menneskerettsloven $\S 3 .{ }^{12}$ Det er også et spørsmål om Grunnloven $\S 92$ innebærer at disse instrumentene nå har grunnlovs rang. ${ }^{13}$ Norge er videre folkerettslig forpliktet til vern av organisasjonsfriheten etter Den reviderte europeiske sosialpakt (ESP) art. 6 og etter flere ILOkonvensjoner. De mest sentrale ILO-konvensjonene er nr. 87 om organisasjonsfrihet og nr. 98 om kollektive forhandlinger.

Organisasjonsfriheten har både en individuell og en kollektiv side. De henger nært sammen, gjennom forutsetningen om at organisasjonene i arbeidslivet skal kunne virke for sine medlemmenes interesser. For temaet her er det den kollektive siden, nærmere bestemt den funksjonelle organisasjonsfriheten, som er sentral. ${ }^{14}$ Det er ILO-konvensjonene som regulerer den funksjonelle organisasjonsfriheten mest detaljert. Etter ILO-konvensjon 98 artikkel 4 er statene uttrykkelig forpliktet til å fremme regulering av arbeidsforhold gjennom frie forhandlinger og kollektive avtaler.

I praksis fra ILOs organisasjonsfrihetskomité (CFA) er det understreket at tariffpartenes frihet til å forhandle og inngå avtaler - kollektiv autonomi - et fundamentalt aspekt ved organisasjonsfriheten. ${ }^{15}$ ILO-praksis gir nærmere veiledning for hvilke skranker dette innebærer for lovgivers adgang til å begrense tariffpartenes autonomi. Spørsmålet er imidlertid hvilken betydning slik praksis har for norsk rett.

Innholdet i folkerettslige forpliktelser, blant annet ILO-konvensjoner, påvirker forståelsen av intern norsk rett gjennom presumsjonsprinsippet. ${ }^{16}$

Et første spørsmål er hvilken betydning praksisen har for fastleggelse av Norges forpliktelser etter ILO-konvensjon nr. 98, sett isolert. I Rt. 1997 s. 580 (OFS-dommen), som gjaldt bruken av tvungen lønnsnemnd, var Høyesterett svært tilbakeholden med å vektlegge praksis fra ILOs organer. Retten viste til at ILOs organer ikke har kompetanse til å avgjøre forståelsen av

\footnotetext{
${ }^{10}$ Hensynet til «en gjensidig forpliktende regulering mellom tariffpartene» ligger for $\emptyset$ vrig til grunn for bestemmelsen om tariffavtalens ettervirkning i arbtvl. $\$ 8$ tredje ledd, jf. ARD 1990 s. 118 (s. 125).

${ }^{11}$ Norge har tatt et forbehold mot $\varnothing \mathrm{SK}$ artikkel $8 \mathrm{nr} .1$ bokstav d grunnet praksisen med tvungen lønnsnemnd.

${ }^{12}$ Lov 21. mai $1999 \mathrm{nr} .30$ om styrking av menneskerettighetenes stilling i norsk rett (menneskerettsloven).

${ }^{13}$ Se Jens Edvin Skoghøy, «Menneskerettighetenes stilling etter Grunnloven», Lov og Rett, 2014 s. 195-196, som imidlertid ikke forstår bestemmelsen slik.

${ }^{14}$ Nærmere om organisasjonsfrihet på kollektivt nivå, institusjonell og funksjonell organisasjonsfrihet, se Stein Evju, Organisasjonsfrihet, tariffavtaler og streik, Oslo 1982 s. 40-48.

${ }^{15}$ Digest of decisions and principles of the Freedom of Association Committee of the Governing Body of the ILO (Fith revised edition) 2006 avsnitt 925 (heretter Digest).

${ }^{16}$ Rt. 2001 s. 248 (s. 258-259).
} 
konvensjonene med bindende virkning for medlemsstatene (s. 589). I stedet ble det lagt vesentlig vekt på Stortingets og regjeringens forutsetninger ved ratifikasjonen - hvorvidt Norge «mente å begrense adgangen til å regulere retten til streik» (s. 588). Vektlegging av nasjonale forutsetninger ved ratifikasjonen bryter imidlertid med konvensjonsvernets universelle og dynamiske karakter. ${ }^{17}$ Senere har Høyesterett trukket inn komitépraksis fra ECSR ved forståelsen av organisasjonsfriheten etter ESP. ${ }^{18}$ Det restriktive synet på betydningen av ILO-praksis i OFS-dommen kan derfor neppe legges til grunn i dag.

Et annet spørsmål er om ILO-konvensjonene og tilhørende praksis har betydning for forståelsen av organisasjonsfriheten etter andre konvensjoner, som EMK artikkel 11. EMD slo i 2008 fast at ILO-konvensjoner og praksis fra ILOs organisasjonsfrihetskomité har relevans for forståelsen av EMK. ${ }^{19}$ Det skjedde i storkammeravgjørelsen i saken Demir og Baykara mot Tyrkia. ${ }^{20}$ Her slo EMD fast at retten til kollektive forhandlinger er grunnleggende - «an essential element» - i organisasjonsfriheten etter EMK artikkel 11. Vektleggingen av ILOkonvensjoner med tilhørende praksis viser et tydelig taktskifte, og er fulgt opp i senere avgjørelser. ${ }^{21}$ Organisasjonsfrihetens kollektive og funksjonelle side er med dette vesentlig styrket. $^{22}$

Utviklingen kan potensielt ha stor betydning for organisasjonsfrihetens stilling i norsk rett. EMK har status som intern norsk rett med forrang og kan i prinsippet danne grunnlag for å sette en norsk lovbestemmelse til side. At Høyesterett skal benytte samme tolkningsmetode som EMD, betyr at ILO-konvensjoner kan og bør vektlegges ved tolkningen av hvilke skranker som følger av EMK art. 11. ${ }^{23}$ Veien ligger dermed åpen for at de prinsippene som er fastlagt i ILO-praksis, kan sette skranker for norsk lovgivning.

Samtidig vil jeg understreke at det er usikkert hvilken vekt Høyesterett vil legge på ILOpraksis i spørsmål som ikke er klarlagt av EMD. Høyesterett har nemlig gitt uttrykk for en forsiktig holdning i tvilsomme spørsmål og fremhevet prioriteringene bak norsk lovgivning. ${ }^{24}$

Videre vil jeg belyse hvilke føringer ILO-praksis legger, og diskutere hvordan de ivaretas i norsk rett.

\footnotetext{
${ }^{17}$ Stein Evju, Arbeidsrett, Utvalgte artikler 2001-2010, Oslo 2010 s. 688.

${ }^{18}$ Rt. 2001 s. 1413 (s. 1428).

${ }^{19}$ Se særlig avsnitt $100-103$.

${ }^{20}$ EMDs dom 12. november 2008.

${ }^{21}$ Se blant andre EMDs dom 30. april 2013 Tymoshenko m.fl. mot Ukrania og dom 8. april 2014 R.M.T. mot Storbritannia.

${ }^{22}$ Se blant annet Keith Ewing og John Hendy, «The Dramatic Implications of Demir and Baykara», Industrial Law Journal. Vol. 39 (2010) s. 2-51 og Stein Evju, «Fundamental Social Rights vs. Fundamental Freedoms», Europäische Zeitschrift für Arbeitsrecht 2013 s. 312-323, på s. 322.

${ }^{23}$ Rt. 2005 s. 53 (avsnitt 45).

${ }^{24}$ Se blant annet Rt. 2005 s. 533 (avsnitt 45).
} 


\section{Rettsutvikling ved endring av tariffavtaler}

\subsection{Partenes felles rådighet}

Det er grunnleggende at tariffpartene i fellesskap råder over tariffavtalen og utviklingen av den. Tariffpartene bestemmer i fellesskap om avtalen skal endres og $h v a$ endringen skal gå ut på. Arbeidsretten har fremhevet at de overordnede parter «har rådighet over avtalen i materiell og prosessuell forstand», samt at de har tolkningsmonopol. ${ }^{25}$

Tolkningsmonopolet betyr at en dokumentert felles partforståelse legges til grunn, også på tvers av en klar ordlyd. Skriftlighetskravet er altså ikke til hinder for at partene blir enige om en rettsutvikling uten å endre tariffavtalens utforming. Endringer skjer normalt som resultat av forhandlinger etter utløpet av en tariffperiode. Partene kan i prinsippet bli enige om endringer i løpet av tariffperioden, men det skjer sjelden.

Tariffpartene er forpliktet etter tariffavtalen som etter enhver annen avtale. Den ene part kan holde den andre erstatningsansvarlig for avtalebrudd på kontraktsrettslig grunnlag. Tariffpartene også holdes ansvarlige for medlemmenes avtalebrudd etter arbtvl. § 9 første ledd, men bare dersom foreningen er «skyld i bruddet eller i fortsettelsen av det tariffstridige forholdet».

\subsection{Uenighet om endring i avtalen}

Partene kan være uenige om hvorvidt avtalen $b \phi r$ endres. Da foreligger det en interessetvist, en tvist «om ordningen av fremtidige arbeidsvilkår ... som ikke omfattes av en tariffavtale», jf. arbtvl. § 1 bokstav j. Interessetvister løses ved forhandlinger mellom partene og eventuelt ved arbeidskamp. I tariffperioden - den enkelte avtales gyldighetstid - gjelder fredsplikt, jf. arbtvl. $\S 8$ annet ledd. ${ }^{26}$

En part kan si opp avtalen og kreve forhandlinger ved tariffperiodens utløp. I utgangspunktet har den andre part ikke noe ansvar i form av plikt til å føre forhandlinger eller til å bidra konstruktivt. Det kan imidlertid utløse en plikt til å delta i megling. Der forhandlinger ikke føres, eller det blir brudd i forhandlingene, kan Riksmekleren nedlegge et midlertidig forbud mot arbeidskamp, såfremt arbeidskampen kan «medføre skade for allmenne interesser», jf. arbtvl. § 19 første ledd. Da skal partene også «straks» innkalles til mekling, jf. arbtvl. § 20 første ledd. Det følger av arbtvl. § 21 at partene har plikt til å møte når de kalles inn til mekling.

Systemet er at partene selv må finne en løsning, eventuelt ved bruk av arbeidskamp. Da er det maktkamp, ikke rettslig ansvar, som avgjør om tariffavtalen endres. I ytterste konsekvens kan tvisten bli løst ved statlig inngripen, ved tvungen lønnsnemnd. Det skjer ved et lovvedtak som nedlegger forbud mot arbeidsstans og overlater til Rikslønnsnemnda å avgjøre tvisten. Rikslønnsnemndas avgjørelse har samme virkning som en tariffavtale. ${ }^{27}$

\footnotetext{
${ }^{25}$ ARD 2016 s. 61 (avsnitt 77).

${ }^{26}$ Tariffavtalen må altså være oppsagt, og oppsigelsestiden må være utløpet. For å kunne iverksette lovlig arbeidskamp må det i tillegg være gitt plassoppsigelse, fristene for denne må være utløpt, og mekling må være avsluttet, jf. arbtvl. $\S 18$ og 25.

${ }^{27}$ Jf. lov 27. januar 2012 nr. 10 om lønnsnemnd i arbeidstvister (lønnsnemndsloven) $§ 2$.
} 
Organisasjonsfriheten stiller imidlertid strenge krav til begrunnelsen for slike inngrep i partenes autonomi. Det grunnleggende er at inngrepet må være nødvendig ut fra offentlige interesser (offentlig orden og sikkerhet, vern av andres rettigheter og friheter eller til beskyttelse av liv, helse og velferd). ${ }^{28}$ Tvungen lønnsnemnd med en hovedsakelig $\varnothing$ konomisk begrunnelse har møtt kritikk fra internasjonale kontrollorganer. ${ }^{29}$ Også EMD har reservert seg mot at en rent $\varnothing$ konomisk begrunnelse er nok. ${ }^{30}$ Dersom en norsk domstol skal prøve tvungen lønnsnemnd opp mot EMK artikkel 11, vil det nå måtte ses hen til denne praksisen.

Uenighet om hvorvidt tariffavtalen er endret, er et annet spørsmål. Tvist om forståelsen av en tariffavtale eller krav som bygger på den, er en rettstvist, jf. arbtvl. § 1 bokstav i. For rettstvister gjelder total fredsplikt, de skal ikke løses ved arbeidskamp, jf arbtvl. § 8 første ledd. Begge parter har et ansvar for å forhandle om en løsning. Avtaleverket fastsetter prosedyrer for dette. ${ }^{31}$ Før Arbeidsretten skal kunne behandle en tolkningstvist, må det foreligge en protokoll eller et bevis for at det er ført forhandlinger, jf. arbtvl. § 45 fjerde ledd.

Den part som hevder en endret forståelse av tariffavtalen, har et ansvar i form av en risiko for uklarhet. Ordlyden har gjennomgående stor vekt ved tolkning av tariffavtaler, det har sammenheng med at avtalen binder flere enn partene. ${ }^{32}$ Arbeidsretten har lagt til grunn at den språkbruk og forståelse som var aktuell da bestemmelsen først ble tatt inn i tariffavtalen, danner utgangspunktet for tolkningen. ${ }^{33}$ Samtidig har tariffhistorien - tariffpartenes forståelse og praktisering av avtalen - gjennomgående betydelig vekt. ${ }^{34}$ Men det er lite rom for utfylling eller lemping ut fra rimelighetshensyn. ${ }^{35}$ Avtalene er balanserte instrumenter, utviklet over tid av jevnbyrdige parter, med egne mekanismer for løsning av interessetvister.

Disse tolkningsprinsippene bidrar til at tariffavtaler i liten grad tolkes dynamisk. Avtalene tolkes med en særlig respekt for partenes frihet og vilje. Det har sammenheng med organisasjonsfriheten og kollektiv autonomi. Endringer forutsettes å skje etter forhandlinger, ved tariffrevisjonen.

\subsection{Kobling til lovregler}

Tariffavtaler kan være koblet til lovregler. Spørsmålet er hvilken betydning rettsutvikling ved lovendringer eller endret forståelse får for forståelsen av tariffavtalen. Dette er et tolkningsspørsmål som ikke påvirker partenes ansvar for å etterleve selve avtalen.

Partene kan ha forutsatt at bestemte regler vil gjelde. Utgangspunktet er, som for avtaler ellers, at hver part har risikoen for egne forutsetninger. Hvis tariffavtalen er inngått under

\footnotetext{
${ }^{28}$ Stokke, Nergaard og Evju 2013 s. 167.

${ }^{29}$ Det er eksempler både fra CFA og fra komiteen som håndhever ESP, European Committee of Social Rights, ECSR, se nærmere Stokke, Nergaard og Evju 2013 s. 169.

${ }^{30}$ EMDs avgjørelse 27. juni 2002 OFS mot Norge. EMD fant imidlertid at lønnsnemnd i OFS-saken ikke var en krenkelse mot EMK artikkel 11, og avviste saken.

${ }^{31}$ Se for eksempel Hovedavtalen LO-NHO § 2-3.

${ }^{32}$ Se for eksempel Rt. 2004 s. 297 (avsnitt 49).

${ }^{33}$ Se et tydelig uttrykk for dette i ARD 1986 s. 124 (s. 133).

${ }^{34}$ Se for eksempel ARD 2004 s. 218.

${ }^{35}$ Smith Ulseth 2012 s. 336- 338.
} 
forutsetning om at visse regler gjelder, må det klargjøres. Ordlydens sterke stilling gir en særlig motstand mot å innfortolke forutsetninger som ikke er kommet til uttrykk. ${ }^{36}$

Arbeidsrettens praksis gir eksempler på at ordlyden legges til grunn selv ved fundamentale endringer i rettsreglene som omgir tariffavtalen. ARD 1981 s. 553 gjaldt hvilken tariffavtale som skulle gjelde for cateringpersonell på et såkalt «flotell», en flyttbar plattform som huset personell i oljebransjen. Flotellet var koblet til en fast plattform og var derfor egnet som en fast installasjon, underlagt arbeidsmiljølovens regler og vanlige skatteregler. En tariffavtale for cateringspersonell på faste installasjoner var gjort gjeldende i tråd med dette. I januar 1981 fikk imidlertid floteller status som flyttbar plattform og ble omfattet av sjøfartslovgivningen og regler om sjømannsskatt. N.A.F. mente de kunne si seg løst fra gjeldende overenskomst for så vidt gjaldt cateringpersonalet, og at en overenskomst for mobile rigger i stedet skulle legges til grunn. Arbeidsretten tolket imidlertid brevet som var påberopt som tariffrettslig grunnlag «strengt etter ordlyden». Dersom arbeidsgiversiden ville legge mer i ordlyden, burde de tatt det opp i forhandlingene. Når det ikke var gjort, var det «rimelig at de må ta belastningen for den uklarhet som er oppstått» (s. 564). Arbeidsgiverforeningen kunne dermed ikke si seg løst fra tariffavtalen selv om den åpenbart bygget på et helt annet rettslig regime. De utfordringene rettsutviklingen skapte, måtte partene løse ved neste tariffrevisjon.

Videre kan partene kan henvise til eller inkorporere en lovtekst i tariffavtalen. Utgangspunktet er da at lovregelen blir en tariffavtalenorm. Det er lagt til grunn i Arbeidsrettens praksis og er sagt klart av Høyesterett i Rt. 2012 s. 1702 (avsnitt 48).

Spørsmålet er hvilken betydning det får for tariffavtalen hvis lovregelen endres. Er det innholdet på avtaletidspunktet eller den til enhver tid gjeldende lovregel som utgjør tariffnormen? I Arbeidsrettens praksis er det lagt til grunn en presumsjon mot at tariffavtalenormen endrer seg i takt med lovregelen. Begrunnelsen er at partene «vil miste herredømme over de endringer og tillegg partene har blitt enige om for tariffperioden, noe som vil kunne få vidtrekkende konsekvenser». ${ }^{37}$

I ARD 2012 s. 126 poengterte retten på lignende måte at det må «foreligge tilstrekkelig klare holdepunkter for å legge til grunn at tariffpartene har overlatt til lovgiver å avgjøre omfanget av den tariffestede retten til sykelønn» (avsnitt 60). Den part som ønsker en tariffnorm som endrer seg avhengig av lovregelens utvikling, har altså et særlig ansvar for å klargjøre dette overfor motparten. Også her ser vi en motstand mot en dynamisk forståelse av tariffavtalen.

\section{Rettsutvikling ved endring i lovregler}

\subsection{Nærmere om organisasjonsfrihetens skranker}

I likhet med andre avtaler kan tariffavtaler ikke stride mot lov. Bestemmelser i tariffavtale som strider mot tvingende lovgivning, vil som et klart utgangspunkt være ugyldige. Men organisasjonsfriheten setter skranker for adgangen til å gripe inn i tariffpartenes autonomi

\footnotetext{
${ }^{36}$ Kjetil Drolsum Sandnes «Tolkning av tariffavtaler», Arbeidsrett og arbeidsliv, Bind 7 s. 145-273 (2014), på s. 177-183.

${ }^{37}$ ARD 2011 s. 175 (avsnitt 61).
} 
som i prinsippet kan lede til at en klar norsk lovbestemmelse settes til side. ILO-organenes praksis belyser de nærmere skrankene.

Utgangspunktet er at statlige myndigheter bør avstå fra enhver begrensning i tariffpartenes frihet til å forhandle og regulere arbeidsvilkår i tariffavtale - «refrain from any inferference which would restrict this right or impede the lawful exercise thereof». ${ }^{38}$ Et annet viktig utgangspunkt gjelder prosessen. Forut for enhver begrensning bør myndighetene føre drøftelser med tariffpartene «in an effort to obtain their agreement». ${ }^{39}$

På den annen side er det klart at begrensninger kan være tillatelige. Staten er opplagt ikke helt avskåret fra å regulere lønns- og arbeidsvilkår ved lov, og rammene for alminnelig handlefrihet - «the law of the land»- gjelder også for organisasjonene. ${ }^{40}$

Organisasjonsfriheten setter imidlertid en klar grense for å endre selve tariffavtaleinnholdet ved lov. Statene «should refrain from intervening to alter the content of freely concluded collective agreements», og skal ikke hindre anvendelsen av inngåtte avtaler. ${ }^{41}$ Det er særlig fremhevet at lovgivning ikke bør endre tariffavtalers innhold $i$ tariffperioden. Selv ved behov for en stabiliserende lønnspolitikk bør eksisterende tariffavtaler gjelde ut sin gyldighetstid. ${ }^{42}$ Dersom myndighetene $\varnothing$ nsker å bringe tariffavtalene i samsvar med økonomisk politikk, bør tariffpartene heller søkes overtalt til det. Organisasjonsfrihetskomiteen har sagt klart at tilsidesetting av tariffavtalens innhold er en krenkelse forhandlingsfriheten. ${ }^{43}$

En reell forhandlingsfrihet krever at avtaleinnholdet blir respektert «at the very least for the duration of the agreement». ${ }^{44}$ En sentral retningslinje er altså at lovgivning ikke skal sette tariffavtalevilkår til side i tariffperioden. Praksis viser at det må gjelde uansett om lovgivningen skjerper eller svekker vernet av arbeidstakere. ${ }^{45}$

Samtidig er forhandlingsfriheten nært knyttet til forbedring av arbeids- og levevilkår, jf. «to seek to improve the living and working conditions». ${ }^{46}$ Lovgivning som setter et maksimumsvern, slik at opparbeidede rettigheter settes til side, er derfor klart mer problematisk enn lovgivning som skjerper minimumsvernet. Lovgivning som innebærer at partene må reforhandle opparbeidede rettigheter, anses å stride mot forhandlingsfriheten - «is contrary to the principles of collective bargaining». ${ }^{47}$

Begrensninger i form av maksimumsvern kan dermed utgjøre en krenkelse av organisasjonsfriheten selv om de først får betydning ved tariffavtalens utløp.

Organisasjonsfrihetskomiteen har rettet skarp kritikk mot Danmark for en lovendring som kun satte grenser for fremtidige tariffavtaler på et felt der partene hadde hatt betydelig frihet og

\footnotetext{
${ }^{38}$ Digest avsnitt 881.

${ }^{39}$ Ibid. avsnitt 999.

${ }^{40}$ ILO konvensjon nr. 87 artikkel 8.

${ }^{41}$ Digest avsnitt 1001 og 1011.

${ }^{42}$ Ibid. avsnitt 1007.

${ }^{43}$ Ibid. avsnitt 1008.

${ }^{44}$ CFAs rapport i sak 2171 mot Sverige avsnitt 1048.

45 Ibid., se nærmere i punkt 5.3.2.

${ }^{46}$ Digest avsnitt 881.

${ }^{47}$ Digest avsnitt 1020.
} 
etablert et tariffavtalt system. ${ }^{48}$ Nye regler for deltidsarbeid var til hinder for videreføring av tariffavtalte rettigheter og ga forrang for individuelle avtaler. Denne begrensningen var ikke forenelig med organisasjonsfriheten.

Det er imidlertid forutsatt at inngrep ved lov kan aksepteres ved «in a situation of acute crisis». ${ }^{49}$ Her er det en klar parallell til adgangen til å gripe inn i selve forhandlingene og $\mathrm{i}$ utøvelse av streikeretten. ${ }^{50}$

På denne bakgrunn skiller jeg i det følgende mellom rettsutvikling som utvider og begrenser kollektiv autonomi, og mellom begrensninger i form av skjerpet minimumsvern og begrensninger i form av maksimumsvern - en sperre for bedret vern gjennom tariffavtale.

\subsection{Utvidelser av kollektiv autonomi}

Lovendringer som overlater spørsmål som tidligere har vært lovregulert, til partenes avtale, utvider rommet for kollektiv autonomi. Flere spørsmål kan bli gjenstand for kollektive forhandlinger og avtaleregulering. Innholdet i eksisterende tariffavtaler påvirkes som et klart utgangspunkt ikke.

Slik rettsutvikling kan være begrunnet i et $\emptyset$ nske om $\emptyset \mathrm{kt}$ avtalefrihet for de individuelle parter. Tariffpartene har imidlertid ikke noe ansvar for å liberalisere eksisterende tariffavtaler. Partene står fritt til å beholde tariffregler som begrenser den individuelle avtalefriheten. Den rettsutviklingen som er $\emptyset$ nsket av lovgiver, blir derfor ikke nødvendigvis realisert.

Dette illustreres av endringen i arbeidsmiljølovens arbeidstidsregler i 2015, der blant annet reglene om gjennomsnittsberegning og alternative turnusordninger myket opp. ${ }^{51}$

Begrunnelsen var de enkelte arbeidsgivere og arbeidstakeres behov for fleksibilitet. ${ }^{52} \mathrm{I}$ forarbeidene er det sagt klart at effekten av lovendringen beror på om tariffpartene velger å tilpasse innholdet til lovgivningen. ${ }^{53}$

Tilbakeholdenheten fra lovgiver var antakelig nødvendig. Arbeidstid er et felt der partene har hatt betydelig frihet og blitt enige om omfattende reguleringer i tariffavtale. Dersom lovgiver hadde fors $\varnothing \mathrm{kt}$ å fremtvinge en liberalisering ved å forby strengere verneregler i tariffavtale eller ved fraviksadgang for de individuelle parter, ville det vært en klar krenkelse av organisasjonsfriheten.

\subsection{Begrensninger i kollektiv autonomi: Skjerpet minimumsvern}

\subsubsection{Innledning}

Nye eller skjerpede regler i vernelovgivningen setter strengere krav til hva tariffpartene kan avtale. Kjernen i forhandlingsfriheten - adgangen til å fremforhandle bedre rettigheter - er imidlertid i behold. Organisasjonsfriheten vil derfor primært være et hinder for skjerpelser

\footnotetext{
${ }^{48}$ CFAs rapport i sak 2178 mot Danmark.

${ }^{49}$ Se for eksempel ibid. avsnitt 584.

${ }^{50}$ Se Digest avsnitt 1004 og ovenfor i punkt 2 om kravene til begrunnelse for tvungen lønnsnemnd.

${ }^{51}$ Lov 24. april 2015 nr. 21 om endringer i arbeidsmiljøloven og allmenngjøringsloven (arbeidstid, aldersgrenser, straff mv.), i kraft 1 . juli 2015.

${ }^{52}$ Prop. L 48 (2014-2015) s. 10.

${ }^{53}$ Ibid. s. 13.
} 
som griper inn i avtaleinnholdet i tariffperioden. Arbeidsrettens avgjørelse i ARD 1996 s. 10 er et eksempel på at en slik lovendring. Saken gjaldt en tariffavtale for flyttbare innretninger på kontinentalsokkelen, som fastsatte at «oppsigelse regnes fra dato til dato». Dette var løsningen etter sjømannsloven, som gjaldt for slik virksomhet. Fra 1993 ble virksomheten imidlertid ført inn under arbeidsmiljøloven, og etter denne skulle oppsigelsesfrister løpe «fra og med den første dag i måneden etter at oppsigelsen har funnet sted». ${ }^{54}$ Reglene om oppsigelsesfrister kunne opprinnelig fravikes ved skriftlig avtale eller tariffavtale, men ved lovendring i 1995 ble fraviksadgangen begrenset. Før oppsigelse hadde funnet sted, kunne avtale om kortere oppsigelsesfrister etter endringen kun inngås mellom de lokale partene i tariffbundne virksomheter. Minimumsvernet ble altså skjerpet ved at adgangen til tariffavtalte fravik ble begrenset. Arbeidsretten la til grunn at lovendringen måtte få virkning for bestående tariffavtaler. Tariffavtalens beregningsregel kunne gi kortere frister enn lovens, og den ble derfor funnet ugyldig.

Etter min vurdering burde Arbeidsretten tolket lovendringen innskrenkende og ikke satt tariffvilkåret til side. Lovens ordlyd sa at avvikende avtale «kan ... bare inngås» av lokale parter. Bestemmelsen kunne dermed forstås slik at den gjaldt inngåelse av $n y$ tariffavtale med avvikende regler. Forholdet til eksisterende tariffavtaler er ikke kommentert i forarbeidene. ${ }^{55}$ Formålet med endringen var å hindre at arbeidsgivere benyttet sin maktposisjon ved avtaleinngåelsen til å avtale svært korte oppsigelsesfrister med den enkelte arbeidstaker. Det ville blitt like godt ivaretatt selv om tariffvilkåret hadde fått stå ut perioden.

Gjennom EØS-avtalen har EU-retten vært en viktig drivkraft i rettsutviklingen i arbeidslivet i senere år. Sekundærlovgivningen fastsetter normalt et minimumsvern av arbeidstaker og har vanligvis form av individuelle rettigheter. I land med sterke kollektive tradisjoner, som i Skandinavia, har det lenge vært en bekymring for at slik regulering over tid skal undergrave kollektiv autonomi - selv om den skjerper vernenivået og selv om det i en del tilfeller er åpnet for fravik ved tariffavtale. ${ }^{56}$

Videre skal jeg diskutere noen problemstillinger som kan oppstå i samspillet mellom skjerpede verneregler og tariffavtaler. Jeg tar utgangspunkt $i$ to felt der rettsutviklingen i senere år har vært betydelig og drevet frem av EU-rettslige regler: diskrimineringsvern og innleie av arbeidskraft.

\subsubsection{Styrket diskrimineringsvern}

Det siste tiåret er vernet mot diskriminering vesentlig utvidet og skjerpet. I dag har vi generelt virkende lover som setter forbud mot diskriminering på grunn av kjønn, etnisitet, religion, livssyn, nedsatt funksjonsevne, seksuell orientering, kjønnsidentitet og kjønnsuttrykk. ${ }^{57}$ Innenfor arbeidslivet setter arbeidsmiljøloven i tillegg forbud mot diskriminering på grunn av

\footnotetext{
${ }^{54}$ Jf. daværende arbeidsmiljølov (1977) § $58 \mathrm{nr} .4$.

${ }^{55}$ Ot.prp. nr. 50 (1993-94) s. 191 og s. 236.

${ }^{56}$ Ruth Nielsen, «The Europeanization of Nordic Labour Law», Scandinavian Studies in Law, Vol. 43 (2002) s. 37-75.

${ }^{57}$ Lov 21. juni 2013 nr. 59 om likestilling mellom kjønnene, lov 21. juni 2013 nr. 60 om forbud mot diskriminering på grunn av etnisitet, religion og livssyn, lov 21. juni $2013 \mathrm{nr}$. 61om forbud mot diskriminering på grunn av nedsatt funksjonsevne, lov 21. juni 2013 nr. 58 om forbud mot diskriminering på grunn av seksuell orientering, kjønnsidentitet og kjønnsuttrykk.
} 
politisk syn, medlemskap i arbeidstakerorganisasjon, alder, samt deltids- eller midlertidig ansettelse.

Retten til ikke å bli diskriminert er en grunnleggende rettighet med forankring i Grunnloven $\S 92$ og i menneskerettskonvensjoner med forrang i norsk rett. Staten har en positiv forpliktelse til å innrette lovgivningen slik at den gir vern mot diskriminering også mellom private parter. ${ }^{58}$ Vernet knyttet til kjønn gjennomfører dessuten EØS-rettslige forpliktelser. ${ }^{59}$ Myndighetenes ansvar for å sikre diskrimineringsvern kan dermed komme på kollisjonskurs med ansvaret for å respektere organisasjonsfriheten. Utformingen av diskrimineringsvernet og rettspraksis viser hvordan dette avveies i norsk rett.

I utgangspunktet er diskrimineringsvernet gitt forrang. Tariffavtalte bestemmelser som strider mot diskrimineringsreglene er ugyldige, jf. aml. § 13-9. Samtidig er det eksempler på tilbakeholdenhet der endringer i diskrimineringsvernet har direkte betydning for tariffavtalte ordninger. Skjerpelsene i vernet mot aldersdiskriminering illustrerer det.

Tidligere kunne arbeidsforhold bli brakt til opphør uten hinder av de vanlige stillingsvernsreglene etter fylte 70 år. Lavere, tariffavtalte aldersgrenser har imidlertid vært utbredt. Etter innføringen av et forbud mot aldersdiskriminering i arbeidsmiljøloven, måtte slike grenser være saklig begrunnet og ikke uforholdsmessig inngripende for å være lovlige. Nylig ble disse bestemmelsene i aml. $§ 15-13$ a endret, og vernet mot aldersdiskriminering ble da ytterligere skjerpet. ${ }^{60}$ Grensen er hevet til 72 år, og adgangen til lavere grenser i tariffavtale er strammet inn. Kravet til saklighet og forholdsmessighet er i behold, jf. fjerde ledd. Men utgangspunktet er nå at grensen ikke kan settes lavere enn 70 år, må gjøres kjent for arbeidstakerne, praktiseres konsekvent og gi rett til en tilfredsstillende pensjonsordning, jf. tredje ledd. ${ }^{61}$ Før $\varnothing$ vrig kan lavere grenser bare settes der det er nødvendig av hensyn til helse og sikkerhet, jf. annet ledd. Endringen har åpenbar betydning for gyldigheten av en rekke tariffavtalte ordninger.

Departementet fant det imidlertid «ikke ønskelig» å gripe inn i tariffavtaleinnholdet i tariffperioden, og fastsatte en overgangsordning. ${ }^{62}$ I endringsloven heter det at «bestemmelser i tariffavtale om lavere grenser enn 70 år for opphør av arbeidsforhold kan beholdes inntil tariffavtalen utløper». Her ligger hensynet til organisasjonsfriheten som et taust premiss.

Overgangsordningen er nødvendig for ikke å krenke organisasjonsfriheten. En lignende lovendring i Sverige ble i 2003 ansett som et brudd på organisasjonsfriheten. I Lag (1982:80) om anställningsskydd (LAS) $§ 32$ a ble det i 2001 innført en rett til å fortsette i arbeid til utgangen av måneden arbeidstakeren fyller 67 år med mindre annet er fastsatt i LAS. ${ }^{63}$ Det var satt en sluttdato for gyldigheten av lavere aldersgrenser i tariffavtale, uavhengig av om

\footnotetext{
${ }^{58}$ NOU 2009: 14 Et helhetlig diskrimineringsvern s. 45.

${ }^{59}$ Vernet knyttet til andre grunnlag, som Direktiv 2000/78/EF (rammedirektivet), bygger også til dels på EUdirektiver, men gjennomføringen er basert på en politisk beslutning og er ikke en forpliktelse etter EØS-avtalen, jf. St.prp. nr. 11 (2003-2004) s. 2.

${ }^{60}$ Endringslov 24. april 2015 nr. 21.

${ }^{61}$ Lavere grenser skal dessuten drøftes med tillitsvalgte, jf. tredje ledd siste punktum.

${ }^{62}$ Prop. 48 L (2014-2015) s. 57.

${ }^{63}$ Lag (2001:298).
} 
tariffperioden var utløpt. ${ }^{64}$ Svenske myndigheter hadde vist til at lovendringen var en svært viktig del av reformeringen av pensjonssystemet, som var tvingende nødvendig og av stor samfunnsmessig betydning. De påpekte også at formålet var å ivareta arbeidstakernes behov under den nye ordningen, og at tariffpartene ikke vist vilje til å finne løsninger. ${ }^{65}$ Komiteen fant likevel at inngrepet i løpende tariffavtaler var i strid med prinsippet om forhandlingsfrihet, og viste til at avtaleinnholdet i det minste - «at the very least» - må respekteres i tariffperioden. ${ }^{66}$

Videre er hensynet til partenes autonomi er gitt et visst gjennomslag ved vurderingen av om det foreligger diskriminering. Vurderingen av om en tariffbestemmelse er diskriminerende, beror i alminnelighet på om bestemmelsen utgjør direkte eller indirekte forskjellsbehandling knyttet til beskyttede grunnlag, og om den er saklig begrunnet, nødvendig og ikke uforholdsmessig. Det er klarlagt at adgangen til saklig forskjellsbehandling i arbeidslivet skal tolkes i overensstemmelse med unntaksadgangen etter rammedirektivet. ${ }^{67}$ Praksis fra EUdomstolen er sentral for den nærmere grensedragningen selv for diskrimineringsforbud som ikke gjennomfører EØS-rettslige forpliktelser. EU-domstolen har understreket at tariffavtaler må være i overensstemmelse med direktivet. ${ }^{68}$ Men samtidig har statene - og til dels tariffpartene - en skjønnsmargin med hensyn til hvilke saklige formål man søker å fremme. ${ }^{69}$

Diskrimineringsvernets nærmere innhold utvikles gradvis, gjennom praksis. Tariffvilkår partene har antatt er lovlige, kan komme i strid med diskrimineringsvernet etter hvert som innholdet utpensles gjennom praksis. Dette utfordrer kollektiv autonomi. Det gir en usikkerhet ved forhandlingene om tariffavtalen kan gjennomføres som forutsatt, som det kan være vanskelig å avklare. Dersom deler av avtalen skjæres bort som ugyldig, vil den avtalen som står igjen, lett bli ubalansert. Forhandlingsfrihet forutsetter nettopp en «give-and-take process» og «reasonable certainty that negotiated instruments will be honoured». ${ }^{70}$ Hensynet til kollektive autonomi tilsier derfor en viss forsiktighet ved å sette tariffavtalte vilkår til side som ugyldige.

I Arbeidsrettens praksis er det gitt et rom for kollektiv autonomi gjennom forholdsmessighetsvurderingen. ARD 2012 s. 433 gjaldt en tariffavtalt ordning om ressurspool for kabinansatte, som innebar en indirekte forskjellsbehandling på grunn av kjønn. Ordningen var likevel lovlig idet den var saklig, nødvendig og forholdsmessig. Ved forholdsmessighetsvurderingen ble det særlig lagt vekt på at ordningen ikke ensidig tilgodeså arbeidsgivers interesser, men representerte «en avveining mellom hensynet til virksomhetens behov for arbeidskraft og de ansatte» og at arbeidstakersiden hadde foretatt bevisste valg

\footnotetext{
${ }^{64}$ Tariffavtalte vilkår i strid med lovbestemmelsen fikk vedvare etter lovens ikrafttredelse 1. september 2001, men ikke lenger enn ut 2002.

${ }^{65}$ CFAs rapport i sak 2171 mot Sverige, særlig avsnitt 1035 og avsnitt 1043.

${ }^{66}$ Avsnitt 1047 og 1048.

${ }^{67}$ Det er slått fast både for arbeidsmiljølovens og sjømannslovens (i dag skipsarbeidslovens) del, se Rt. 2010 s. 201 (avsnitt 46-56), Rt. 2011 s. 609 (avsnitt 72), Rt. 2011 s. 964 (avsnitt 44), Rt. 2012 s. 219 (avsnitt 46) og ARD 2013 s. 227 (avsnitt 133).

${ }^{68}$ Se for eksempel sak C-45/09 Rosenbladt, Sml. 2010 s. I-9391. Se også sak C-447/09 Prigge, Sml. 2011

s. I-8003.

${ }^{69}$ Se for eksempel Rosenbladt avsnitt 41.

${ }^{70}$ Digest avsnitt 941.
} 
under forhandlingene (avsnitt 83). ARD 2013 s. 227 tar samme utgangspunkt. En 14timersgrense for innmelding i en tariffavtalt pensjonsordning representerte ikke en avveining av tariffpartenes interesser. Det ledet til at vilkåret var uforholdsmessig og ulovlig, se nærmere rett nedenfor. Vilkår som er resultat av en reell forhandling - en «give-and-take process» - vil lettere stå seg mot diskrimineringsvernet.

Respekten for kollektiv autonomi er ikke like fremtredende i Rt. 2012 s. 219. Saken gjaldt lovligheten av en tariffavtalt aldersgrense på 60 år for helikopterpiloter. Grensen innebar en direkte forskjellsbehandling på grunn av alder. Retten fant forskjellsbehandling muligens var saklig ut fra hensynet til verdig avgang, men at en grense for tvungen avgang ikke var nødvendig for å ivareta dette formålet og heller ikke forholdsmessig (avsnitt 71). Heller ikke hensynet til å sikre raskere avansement for yngre flyvere eller ønsket om å bevare en god pensjonsordning ble ansett tilstrekkelig. Høyesterett la ikke vekt på at aldersgrensen var et resultat av kollektive forhandlinger, men kunne tvert imot «ikke se at partene i arbeidslivet skal ha større frihet enn arbeidsgiveren til å sette til side forbudet mot forskjellbehandling på grunn av alder for å gi yngre arbeidstakere raskere avansementsmulighet» (avsnitt 72). Vurderingene var nært knyttet til føringer i EU-domstolens praksis. ${ }^{71}$

Diskrimineringsforbudet kan ramme både avtalevilkår og konkrete handlinger og unnlatelser. Det må derfor tas stilling til om selve tariffvilkåret, eller bare anvendelsen av det, utgjør diskriminering og skal kjennes ugyldig. Rettspraksis viser at tariffavtalens utforming har avgjørende betydning for hvor langt ugyldighetsvirkningen rekker. Hensynet til kollektiv autonomi bidrar til å begrense ugyldighetsvirkningen til konkrete handlinger fremfor å ramme tariffvilkåret som sådan.

Aldersgrensen for helikopterpilotene i Rt. 2012 s. 219 utløste tvungen avgang. Diskrimineringen var dermed en nødvendig følge av tariffvilkåret. Høyesterett satte tariffvilkåret til side, og arbeidstakerne fikk dom på at de fortsatt var ansatt.

ARD 1990 s. 148 gjaldt spørsmålet om tariffavtalt lønn var i strid med kravet om lik lønn for kvinner og menn i samme virksomhet som utfører arbeid av lik verdi, som i dag følger av likestillingsloven $\S 21$. Etter tariffavtalen var bioingeniører og avdelingsingeniører lønnet etter ulike stillingskoder, og tre kvinnelige bioingeniører hadde lavere lønn enn tre mannlige avdelingsingeniør ved samme laboratorium. Retten fant at arbeidet hadde lik verdi. Likelønn innebærer ikke at lønnsresultatet nødvendigvis må være likt, men at normene for lønnsfastsettelse skal være de samme. Arbeidsretten poengterte imidlertid at den enkeltes lønn ikke følger uten videre av regulativet, men fastsettes ved den konkrete innplasseringen. Lønnsregulativet var derfor ikke i seg selv i strid med likestillingsloven. Kravet til tariffavtalen var at den måtte «rom for vurderinger som gir kvinner og menn som utfører arbeid av lik verdi, samme lønnsresultat når vilkårene ellers er like» (s. 166). Det var ingen relevante forskjeller som skulle tilsi ulikt lønnsresultat i dette tilfellet. Den lavere avlønningen var dermed i strid med likestillingsloven. Men ugyldighetsvirkningen ble begrenset til den konkret lønnsfastsettelsen. En tariffmessig løsning tilpasset likestillingsloven kunne nås på ulike måter, noen endringer var allerede gjort. Retten kunne ikke ta stilling til «[h]vordan

\footnotetext{
${ }^{71}$ Se særlig avsnitt 65,66 og 69.
} 
partene skal utforme tariffbestemmelser», men måtte nøye seg med å fastslå «det tariffavtalebestemte her rent konkret» var i strid med loven og ugyldig (s. 167).

Saken i ARD 2013 s. 227 gjaldt en 14-timers grense for innmelding i pensjonsordning. Spørsmålet var om grensen stred mot forbudet mot diskriminering av arbeidstaker som arbeider deltid etter arbeidsmiljøloven. ${ }^{72}$ Grensen innebar forskjellsbehandling fordi den i en del tilfeller satte deltidsansatte i en dårligere stilling enn heltidsansatte. Retten tok ikke stilling til om formålet var saklig, da grensen uansett ble ansett uforholdsmessig (avsnitt 142). Her var diskrimineringen ikke en automatisk konsekvens av tariffavtalen. Grunnet samordningen med folketrygdens ytelser kom enkelte deltidsansatte bedre ut. Arbeidsretten fant likevel den tariffavtalte grensen diskriminerende og ugyldig som sådan. Begrunnelsen var at tariffavtalen ikke åpnet for ulike løsninger. Retten antok at en annen grense kunne være lovlig, men overlot til partene «å komme frem til en avklaring med hensyn til om - og i så fall hvilken - grense for medlemskap som skal gjelde, men da slik at det ikke kan stilles krav om minst 14 timer per uke» (avsnitt 153).

Avgjørelsen illustrerer også et dilemma. Kollektiv autonomi tilsier - slik retten påpeker - å overlate spørsmålet om en ny grense til partene. På den annen side taler kollektiv autonomi mot å forrykke balansen mellom partene ved å skjære bort enkelte vilkår i avtalen. I denne saken var partene enige om at det burde være en grense. Slik 14-timersgrensen var satt, kunne Arbeidsretten vanskelig sette en ny grense gjennom tolkning. Spørsmålet er om en konkret lempingsmulighet burde benyttes i større grad, i tilfeller der det kan forankres i partenes felles vilje.

\subsubsection{Styrket vern av innleide arbeidstakere}

Innleie av arbeidskraft er et annet område der det er skjedd en vesentlig rettsutvikling i senere år. Ved gjennomføringen av EUs vikarbyrådirektiv ble innleiereglene endret, og endringene har vært kontroversielle. ${ }^{73}$ Det har sammenheng med at formålet er sammensatt. ${ }^{74}$ Direktivet tar sikte på å beskytte vikarbyråansatte ved å innføre et likebehandlingsprinsipp, jf. artikkel 2 . Skjerpelsen av minimumsvernet for innleide arbeidstakere og samspillet med tariffregulering er tema i inneværende punkt. Direktivet skal imidlertid også skape arbeidsplasser ved å utvikle mer fleksible former for arbeidskontrakter. ${ }^{75}$ Hvorvidt direktivet dermed setter et maksimumsvern som begrenser statenes adgang til å gi verneregler, er temaet i neste punkt.

Likebehandlingsprinsippet innebærer at «de væsentligste arbejds- og ansættelsesvilkår» for arbeidstakere som leies ut, skal være minst like gode som om vedkommende var ansatt hos innleier, jf. art. 5 nr. 1. Vilkårene i innleiebedriften danner dermed et minimumsvern. Likebehandlingsprinsippet er gjennomført i aml. § 14-12a. Utleiebedriften er i utgangspunktet arbeidsgiver og ansvarlig for gjennomføringen av likebehandlingsprinsippet. Samtidig er

\footnotetext{
${ }^{72}$ Det var også reist spørsmål om grensen innebar indirekte diskriminering på grunn av kjønn, men saken ble løst etter arbeidsmiljølovens regler.

${ }^{73}$ Direktiv 2008/104/EF.

${ }^{74}$ Andreas van den Heuvel «Bemanningsdirektivet: EF-direktivet om arbeidsleie, fremvekst, regler og konsekvenser for nasjonal rett», Arbeidsrett og arbeidsliv, Bind 5 s. 155-189 (2011) på s. 189-191.

${ }^{75}$ Direktivet har også til formål å anerkjenne vikarbyråer som arbeidsgivere. Reglene om innleie $\mathrm{i}$ arbeidsmiljøloven har dermed klargjort at det er utleier som i utgangspunktet er arbeidsgiver og ansvarlig for oppfyllelsen av lovens verneregler. Innleier er samtidig særskilt pålagt en rekke arbeidsgiverplikter.
} 
innleier særskilt pålagt en rekke arbeidsgiverplikter, og er dermed arbeidsgiver i en viss forstand. Blant annet er innleier solidarisk ansvarlig med utleier for krav på lønn mv. som følger av likebehandlingsprinsippet, jf. aml. § 14-12c. ${ }^{76}$

Direktivet gir et rom for kollektiv autonomi. Tariffavtale som avviker fra likebehandlingsprinsippet, kan inngås dersom «den generelle beskyttelse af vikaransatte respekteres», jf. artikkel 5 nr. 3. I Norge er det gitt forskrift med en slik adgang til å fravike likebehandlingsreglene ved tariffavtale. ${ }^{77}$ Adgangen gjelder for bemanningsforetak som er bundet av tariffavtale med fagforening med innstillingsrett etter arbeidstvistloven, og er knyttet til arbeid innenfor tariffavtalens virkeområde. Et vilkår for fravik er dessuten at den generelle beskyttelsen av arbeidstakerne respekteres, jf. forskriften $\S 3$ tredje ledd. Ifølge forarbeidene innebærer det at partene må avtale «en motvekt til de elementene om beskyttelse som fravikes». ${ }^{78}$ Intensjonen er «å $\emptyset \mathrm{ke}$ muligheten for ansvarlige parter til å etablere praktiske og funksjonelle ordninger». ${ }^{79}$

Tariffpartenes autonomi er altså utformet som en frihet under ansvar. Men innholdet $\mathrm{i}$ ansvaret er uklart: Når er de kompenserende rettighetene gode nok og hvordan skal partene eventuelt stilles til ansvar? Antakelig er det tilstrekkelig at avtalen fastsetter kompenserende rettigheter. I forarbeidene er det fremhevet at partene på representativt nivå har «gode forutsetninger» for å inngå avtaler som balansere de ulike hensynene. Det kan vanskelig tenkes at rettigheter fremforhandlet av større fagforeninger skal settes til side fordi beskyttelsen av arbeidstakerne ikke er respektert.

Likebehandlingsprinsippet er ikke bare lovregulert, det er også tariffestet. Det reiser spørsmål om partene er tariffrettslig forpliktet til ikke å benytte fraviksadgangen. I en rekke landsdekkende tariffavtaler - blant andre industrioverenskomsten mellom LO (Fellesforbundet) og NHO (Norsk Industri) - heter det i fellesbilag 8 om innleie:

«1.3.2 Ansatte i bemanningsforetak/vikarbyrå skal, så lenge innleieforholdet varer, ha samme lønns- og arbeidsvilkår som gjelder i innleiebedriften i samsvar med aml § 14-12 a, (forslag i Prop 74L).»

Tariffavtalen viser til lovbestemmelsen og gjør den i utgangspunktet til en tariffnorm. Det kan likevel reises spørsmål om tariffbestemmelsens nærmere innhold. Mens den stiller krav om «samme lønns og arbeidsvilkår» som i innleiebedriften, krever aml. § 14-12a «minst»samme vilkår. Partene har imidlertid avklart i ettertid at bestemmelsen skal ha «samme meningsinnhold som bestemmelsen i arbeidsmiljøloven $§ 12-14 a$, jf. lov 2012-06-22 nr. $33 \gg .{ }^{80}$

\footnotetext{
${ }^{76}$ Innleier er også pålagt å sikre den innleide et forsvarlig arbeidsmiljø, og er ansvarlig for at arbeidstidsreglene overholdes, jf. aml. § 2-2, og har dessuten en viss opplysningsplikt overfor bemanningsforetaket og tillitsvalgte etter aml. § 14-12b.

${ }^{77}$ Forskrift 6. juli $2015 \mathrm{nr}$. 874 om adgang til ved tariffavtale å fravike reglene om likebehandling ved utleie fra bemanningsforetak, hjemlet i aml. § 14-12a tredje ledd. Fraviksadgangen gjelder vilkårene i § 14-12a første ledd. ${ }^{78}$ Prop. 74 L (2011-2012) s. 61. Fraviket kan omfatte arbeidstakere som ikke er bundet av tariffavtalen, dersom disse på tilsvarende måte gis kompenserende rettigheter.

${ }^{79}$ Ibid.

${ }^{80}$ Protokoll fra møte NHO/Norsk Industri og LO/Fellesforbundet 29. november 2012.
} 
Tariffnormen er etter ordlyden knyttet opp til forslaget i proposisjonen og til loven slik den ble vedtatt i 2012. Det taler mot en dynamisk forståelse. Adgangen til å fravike likebehandlingsprinsippet i tariffavtale ble først fastsatt sommeren 2015. LO var også mot innføringen av en fraviksadgang. ${ }^{81}$ Mye kan derfor tale for at partene er underlagt selvpålagte begrensninger.

Et annet spørsmål er hvem som er pliktsubjekt for det tariffestede likebehandlingsprinsippet. Lovens utgangspunkt er at utleier er ansvarlig. Arbeidstakersiden hevdet imidlertid at bilaget punkt 1.3.2 innebar en selvstendig tariffrettslig plikt for innleier til ikke å leie inn arbeidstakere på vilkår i strid med likebehandlingsprinsippet. I ARD 2015 nr. 1 kom Arbeidsretten til at bestemmelsen ikke innebærer en slik selvstendig plikt for innleier. Henvisningen til aml. § 14-12a ble ansett å tale for utleier som primært ansvarlig, men forståelsen av tariffbestemmelsen måtte bero på en bredere vurdering, og det sammensatte partsforholdet tilsa at punkt 1.3.2 ikke kunne leses isolert. Bilaget punkt 1.3.3 og 1.3.4 pålegger innleiebedriften å medvirke til gjennomføringen av likebehandlingsprinsippet, blant annet ved å gi opplysninger om lønns- og arbeidsvilkår. Innleiebedriften hadde derved en selvstendig tariffrettslig forpliktelse til å medvirke til at den innleide får lønns- og arbeidsvilkår i samsvar med punkt 1.3.2, men punkt 1.3.2 var ikke et selvstendig tariffrettslig vilkår for innleie.

\subsection{Begrensninger i kollektiv autonomi: Maksimumsvern}

Ny lovgivning kan sette grenser for tariffavtalt vern. Et slikt maksimumsvern er ikke bare en bare en begrensning i hva partene kan forhandle om, det er negasjonen av forhandlingsfrihet. Det rammer forhandlingsfrihetens kjerne - adgangen til å fremforhandle bedre rettigheter. Denne typen begrensninger vil raskt komme på kollisjonskurs med organisasjonsfriheten. Konflikten er slående dersom lovgivningen griper inn i løpende tariffavtaler, men er også tydelig der fremtidige tariffavtaler begrenses.

Rettspraksis gir et eksempel på at en tariffavtalt rettighet måtte vike for en ny lov i tariffperioden. I 1988 ble det gitt midlertidige lover om inntektsstopp og inntektsregulering, med forbud mot å gi eller motta økning i inntekt, men med åpning for bestemte individuelle tillegg. ARD 1989 s. 80 gjaldt lovgivningens betydning for en tariffavtale der partene hadde avtalt en opptrappingsplan for lønnsregulering, og der det siste trinnet i opptrappingen gjenstod. Arbeidsretten fant at loven var til hinder for oppfyllelse av den avtalte lønnsforpliktelsen. Lovgiver hadde ment å la loven virke for inngåtte avtaler, og hadde vurdert at det ikke var i strid med tilbakevirkningsforbudet i Grunnloven $\S 97$. Arbeidsretten la dessuten vekt på at lovgivningen var av midlertidig karakter, at den ikke rettet seg spesielt mot tariffpartene, og at den var begrunnet i samfunnsøkonomiske hensyn. Selv om loven var et midlertidig tiltak i en økonomisk krisetid, kan det reises spørsmål om dette i dag er forenelig med organisasjonsfriheten.

Det er et politisk betent spørsmål om vikarbyrådirektivet innebærer et maksimumsvern. Etter arbeidsmiljøloven er adgangen til innleie fra bemanningsforetak sterkt begrenset. Som

\footnotetext{
${ }^{81}$ Prop. 74 L (2011-2012) s. 60.
} 
hovedregel kan det bare leies inn arbeidskraft til arbeid av midlertidig karakter, og innleie i strid med dette gir rett til fast ansettelse hos innleier. ${ }^{82}$ Den såkalte «fireårsregelen» og den nye «treårsregelen» kan gi rett til fast ansettelse hos innleier når innleien har vedvart over lengre tid. ${ }^{83}$ Dette er sentrale verneregler som tar sikte på å sikre fast ansettelse som en hovedregel i norsk arbeidsliv. ${ }^{84}$ Begrensninger i innleieadgangen er også tariffestet. I bilagene om innleie som inngår i en rekke overenskomster, heter det: «Ved innleie av arbeidstakere fra bemanningsforetak/vikarbyrå gjelder arbeidsmiljøloven $§ 14-12 .{ }^{85}$

Spørsmålet er om slike verneregler - i lov og tariffavtale - utgjør en restriksjon i strid med direktivet art. 4. Det er også et spørsmål om hvem som eventuelt kan stilles til ansvar. Dersom nasjonale domstoler skal sette restriksjoner til side, vil tariffparter kunne holde hverandre ansvarlige. Dette var oppe for EU-domstolen i AKT-saken. ${ }^{86}$ Saken gjaldt en finsk tariffavtale med lignende grenser for innleie som i Norge. EU-domstolen fant at staten hadde ansvaret for å vurdere om tariffavtalen utgjorde en restriksjon, og i så fall iverksette tiltak for å fjerne dem:

«... the provision is addressed only to the competent authorities of the Member States, imposing on them an obligation to review in order to ensure that any potential prohibitions or restrictions on the use of temporary agency work are justified ...» (avsnitt 32).

Nasjonale domstoler var derimot ikke forpliktet til å sette restriksjoner til side. Dette kan tenkes å stille seg annerledes der innleien har et grensekryssende element. Nasjonale domstoler har et ansvar for å anvende de traktatfestede tjenestereglene i situasjoner med grensekryssende arbeid eller tjenester. Tariffavtalen i AKT-saken berørte ikke grensekryssende arbeid eller tjenester, så det ble ikke vurdert av EU-domstolen. EUdomstolen tok heller ikke stilling til det sentrale spørsmålet om denne typen verneregler utgjør en restriksjon etter direktivet. Det er dermed fremdeles uavklart om begrensningene i innleieadgangen i norsk rett - i lov eller tariffavtale - strider mot vikarbyrådirektivet. ESA har åpnet «conformity assessment» mot Norge på dette. ${ }^{87}$

Saken kan føye seg inn i rekken av tilfeller der hensynet til tjenesteregler og frihet i markedet kommer i konflikt med organisasjonsfrihet, på bekostning av vern av individet. ${ }^{88} \mathrm{EU}$ domstolens avgjørelse i Laval-saken er et kjent eksempel på at EU-domstolen har gitt tjenestereglene og markedshensynene forrang. ${ }^{89}$ Både på EU-nivå og nasjonalt nivå er det imidlertid grunn til å etterlyse en sterkere vektlegging av organisasjonsfriheten, ikke minst etter EMDs avgjørelse i Demir og Baykara. ${ }^{90}$

\footnotetext{
${ }^{82}$ Jf. aml. § 14-12 første ledd, jf. § 14-9 første ledd bokstav a og § 14-14.

${ }^{83}$ Jf. aml. § 14-12 fjerde ledd, jf. § 14-9 sjette ledd.

${ }^{84}$ Se blant annet Prop. 74 L (2011-2012) s. 44.

${ }^{85}$ Fellesbilag 8 punkt 1.3.1.

${ }^{86}$ Sak C-533/13 AKT EU:C:2015:173.

${ }^{87}$ Brev fra ESA til Arbeids- og sosialdepartementet 8. januar 2015.

${ }^{88}$ For en oversiktsfremstilling med referanser til videre lesning, se Catherine Barnard, EU Employment Law, 4. utgave, Oxford 2012 s. 189-239.

${ }^{89}$ Sak C-341/05 Laval, Sml. 2007 s. I-11767.

${ }^{90}$ Se blant annet Evju 2013 s. $312-323$ på s. 323.
} 


\section{Ansvar for å tilpasse tariffavtalene til samfunnsutviklingen?}

Artikkelen har belyst at tariffpartene har - og skal ha - en betydelig rådighet over hvordan reguleringen av arbeidslivet utvikler seg. Det kan reises spørsmål om tariffpartenes makt bør ledsages av et ansvar for å tilpasse tariffreguleringen til endrede samfunnsbehov.

Tariffpartenes makt er imidlertid ikke én makt. Partene representerer en balansering av makt og samfunnsinteresser, enkelt sagt mellom hensynet til avtalefrihet og verdiskapning og hensynet til vern av det enkelte individ. Avtalefrihet for slike noenlunde likestilte parter antas å maksimere nytte til alles beste. Makt for tariffpartene står derfor ikke i motsetning til samfunnets interesser. Tariffavtalen som reguleringsinstrumentet har en iboende tilpasningsdyktighet. Selv om tariffavtaler oftest utvikler seg gradvis, ved å bygge lag på lag, er det også eksempler på at partene har blitt enige om mer fundamentale endringer når de har sett det nødvendig.

Dessuten tar tariffpartene i praksis et ansvar for tilpasninger til endrede samfunnsbehov. Den norske arbeidslivsmodellen særpreges av et regulert arbeidsmarked, høy organisasjonsgrad og et velfungerende trepartssamarbeid. ${ }^{91}$ Tett samarbeid mellom staten og tariffpartene gir koordinert lønnsdannelse som bidrar til å holde arbeidsledigheten lav, yrkesdeltakelsen høy og gir gode rammebetingelser for virksomhetene. ${ }^{92}$ Autonomi for tariffpartene synes kort sagt å være en nøkkelfaktor for et velfungerende arbeidsliv.

${ }^{91}$ Se blant annet Ot.prp. nr. 88 (2008-2009) s. 11.

${ }^{92}$ NOU 2009: 10 Fordelingsutvalget s. 179, sitert i Rt. 2013 s. 258 (avsnitt 159). 